\title{
Odkryć ukryte... Praca socjalna w Polsce z perspektywy women's/gender/feminist studies
}

\author{
Anna Kola \\ Katedra Pracy Socjalnej, Wydział Nauk Pedagogicznych \\ Uniwersytet Mikołaja Kopernika w Toruniu \\ amkola[]umk.pl \\ Przyjęto: luty 2015; zaakceptowano: czerwiec 2015; opublikowano: lato 2015.
}

\begin{abstract}
Abstrakt
Celem artykułu jest zaprezentowanie rzadkiej i mało rozpowszechnionej perspektywy rozumienia pracy socjalnej nie tylko jako dyscypliny naukowej czy akademickiej, ale także jako określonych działań wspierających. Autorka włącza badania z zakresu studiów nad kobiecością, studiów genderowych oraz feministycznych do analizy profesjonalnej pracy socjalnej, polityki społecznej, praw społecznych itd. W artykule opisuje się akty opresji za pomocą tych współczesnych teorii, które są pomocne dla praktyki pracy socjalnej, wyjaśnia źródła mechanizmów odpowiedzialnych za opresję oraz wskazuje na możliwe rozwiązania.
\end{abstract}

Słowa kluczowe: praca socjalna; gender studies; polityka społeczna; mechanizmy opresji; dyskryminacja.

\section{Ukryta płeć pracy socjalnej}

Pracę socjalną w Polsce można opisać, odwołując się do swoistego paradoksu. Gdy bowiem ma się z nią do czynienia na poziomie praktyki - będąc zarówno klientem/klientką, badaczem/badaczką czy też zarządzającym/zarządzającym pomocą społeczną, oczywiste jest, że to domena kobiet (por. Hicks 2008) ${ }^{46}$. Kobietami są podopieczne, klientki, ofiary kryzysów, bezrobotne przychodzące po zasiłek, ale też ci/te „z drugiej strony”: udzielający pomocy, czyli pracownicy socjalni/pracowniczki socjalne ${ }^{47}$. O kobietach mówi się także, wskazując na „wybitne kreatorki działania społecznego i pracy socjalnej w Europie” (Kantowicz 2014: 120). Jednak konfrontując rzeczywistość ze świa-

\footnotetext{
${ }^{46}$ Tekst poświęcony jest głównie kobietom w pracy socjalnej, choć można byłoby pokusić się o podobny pisany z perspektywy męskiej.

${ }^{47}$ Forma żeńska zawodu „pracownik socjalny”, czyli „pracowniczka socjalna”, de facto nie istnieje - zarówno w działaniach, jak i pracach naukowych, a także popularnonaukowych z tego zakresu.
} 
tem opisanym w pracach dotyczących działań pomocowych, można zauważyć, że płeć dla pracy socjalnej nie tyle ma drugorzędne znaczenie, co raczej nie ma go w ogóle ${ }^{48}$. Jest to o tyle zaskakujące, że o ile zdefiniuje się pracę socjalną, korzystając z różnych perspektyw, włączając odmienne paradygmaty naukowe (choćby perspektywę biograficzną czy funkcjonalno-strukturalną), o tyle okaże się, iż perspektywa kobieca jest dominująca ${ }^{49}$. Nawiązuję tu między innymi do tezy Anny Kotlarskiej-Michalskiej, która we wprowadzeniu do książki pod swoją redakcją, będącą tomem prezentującym teksty wystąpień wygłoszonych przez ich autorów w ramach XXII Zjazdu Polskiego Stowarzyszenia Szkół Pracy Socjalnej, uzasadniając wybór tematu konferencji, pisze: „Nie znaczy to jednak, że na poprzednich zjazdach obecność kobiet była pomijana. Była jednak obecnością ukrytą (podkreślenie - A.M.K), zaznaczaną przy okazji opisów różnych problemów społecznych; częściej w opisach kobiet uwikłanych w role uciśnionych niż kreatorek metod i technik pracy socjalnej” (Kotlarska-Michalska 2014: 9). Dlatego należy sięgnąć po to, co niewidoczne, choć niewątpliwie istniejące (korzystając z narzędzi i teorii pedagogiki emancypacyjnej, jak w przypadku Marii Czerepaniak-Walczak, i/lub krytycznej, by odwołać się do prac Lecha Witkowskiego, Tomasza Szkudlarka, Henry’ego Girouxa, Petera McLarena) i odkryć złożony, często pełen przemocy czy dyskryminacji świat kobiet pomocy społecznej.

\section{Emancypacyjna rola pracy socjalnej - uwagi wokół definicji}

Praca socjalna określana jest na wiele różnych sposobów, odwołujących się do jej zadań, zakresu, wykonawcy, filozofii działania, sponsora itd. Definicje te łączy cel działań, jakim jest wspieranie obywateli w sytuacjach trudnych, kryzysowych czy problemowych i zachęcanie ich do podejmowania prób usamodzielnienia się i uniezależnienia (od systemu pomocy), tym samym do wyjścia z kryzysu/problemu. Sformułowanie powyższe odróżnia pracę socjalna, będącą działaniem o funkcji z zasady emancypacyjnym, od opieki, udzielanej osobom zależnym: chorym, w starszym wieku, dzieciom, niepełnosprawnym. Kategorię „pracy socjalnej” do działań zabezpieczających o charakterze so-

\footnotetext{
${ }^{48}$ Mam tu na myśli przede wszystkim podręczniki do pracy socjalnej, wciąż nieczęste badania naukowe z zakresu pracy socjalnej (ze względu na „młodość” dyscypliny), artykuły w branżowych czasopismach itd.

${ }^{49}$ Problem dostrzegła Anna Kotlarska-Michalska, przewodnicząca Polskiego Stowarzyszenia Szkół Pracy Socjalnej (PSSPS), które co rok współorganizuje (razem z goszczącą jednostką kształcącą pracowników socjalnych) Zjazdy PSSPS. W dniach 18-19 października 2012 roku na Uniwersytecie im. Adama Mickiewicza miał miejsce XXII Zjazd PSSPS oraz seminarium naukowe na temat: $K o$ biety $w$ pracy socjalnej. Kotlarska-Michalska zaprosiła uczestników do udziału w sesji poświęconej trzem grupom zagadnień: (1) udziałowi kobiet w tworzeniu teoretycznych podstaw pracy socjalnej i społecznej; (2) prezentacji dorobku kobiet - organizatorek różnych eksperymentów w pracy socjalnej i pomocy społecznej (tu zaś znalazły się wątki swoiście feministyczne, np. „blaski i cienie feminizacji w zawodzie pracownika socjalnego"); (3) roli kobiet w zarządzaniu pracą socjalną i pomocą społeczną.
} 
cjalnym wprowadziła dopiero Ustawa z 1990 roku o pomocy społecznej. Tym samym przeniesiono działania pomocowe z sektora zdrowia do sektora pracy i polityki społecznej. Ta paradygmatyczna wręcz zmiana przyniosła wiele zmian w pojmowaniu roli i zadań pracowników socjalnych, którzy przestali być opiekunami, a stali się czynnymi wyzwolicielami zmian, animatorami w środowisku. Sama ewolucja tego zawodu jest procesem analogicznym do zmian roli pomocy społecznej. W końcu XIX wieku praca socjalna miała w przeważającym stopniu charakter wolontariacki. Po drugiej wojnie światowej działalność profesjonalizowała się, stając się zawodem. Początkowo posługiwano się określeniem „opiekun społeczny”, które zostało użyte w uchwalonej w Polsce w 1923 roku ustawie o opiece społecznej; w 1966 roku nastąpiła zmiana: wykonawcę czynności opiekuńczych zaczęto nazywać „pracownikiem socjalnym”.

W tym kontekście pojawia się inne ważne określenie, szersze niż sama „praca socjalna”: „usługi socjalne”50, będące według Petera Herrmanna działaniami, których celem jest poprawa samopoczucia jednostki, przy jednoczesnym upoważnieniu jej lub nadaniu danej jednostce prawa. Takie działanie, opierając się na regulacjach prawnych, wyraźnie przyczynia się do wzrostu spójności społecznej (Herrmann 2010: 96). Ponownie przypomina to praktykę emancypacyjną, budującą nową, suwerenną tożsamość osoby.

Same definicje w kontekście postawionego w tekście problemu nieobecności (niewidzialnej obecności) kobiet są ważne, ponieważ - jak pisze Marek Rymsza - „Pracownicy socjalni jako środowisko zawodowe są w Polsce słabiej rozpoznawalni niż instytucja pomocy społecznej, w której większość z nich na co dzień pracuje. Jeszcze słabiej jest rozpoznawalna sama praca socjalna” (Rymsza 2012: 11) ${ }^{51}$. Wskazuje się ponadto na jej odrębność (ze względu na szeroko zakrojony zakres działań oraz typów interwencji), „funkcjonalną generalizację”, co oznacza, że winna służyć wszystkim w takim samym zakresie (Bieńko 2012), i polityczność (Beckett 2010). Według Chrisa Becketta praca socjalna jest „podmiotem politycznym i dlatego sposób, w jaki jest definiowana, konceptualizowana i wdrażana, jest kwestią sporną” (Beckett 2010:16). Badacz wyjaśnia, że chociaż inne obszary życia społecznego - czyli opieka zdrowotna czy edukacja - również stanowią sferę polityczną, to jednak „podstawowe funkcje lekarza, nauczyciela czy policjanta nie wydają się przedmiotem dyskusji, jak w przypadku pracownika socjalnego. Praca socjalna to profesja, któ-

\footnotetext{
${ }^{50}$ Od kilku lat konsultowany jest projekt nowej ustawy o pomocy społecznej (poprzednia została uchwalona 2004 r. - Dz.U. z 2004 r., Nr 64, poz. 593 ze zm.), która definiuje zadania instytucji pomocowych jako „usługi socjalne”, w których nacisk ma być położony na działania profilaktyczne, edukacyjne oraz aktywizacyjne. Zmianę widać także na poziomie języka, bowiem dotychczasowa nazwa „ośrodek pomocy społecznej” ma zostać zmieniona na „Centrum Pomocy i Usług Socjalnych".

${ }^{51}$ Co zaskakuje, na tej samej stronie Rymsza zauważa, że zawód pracownika socjalnego jest bardzo sfeminizowany (przypis nr 2), nie wskazując jednak na żeńską formę zawodu.
} 
rej sam 'charakter' jest sporny” (Beckett 2010:16). W mediach, ale też w debatach naukowych, jak również w gronie polityków czy specjalistów w zakresie polityki społecznej, pojawiają się pytania o to, komu i jak pomagać. Co ma być kryterium oceny klienta - jego dochód, zaangażowanie w życie społeczne czy rodzinne, a może raczej - predyspozycje psychofizyczne (uległość, karność, pracowitość, brak własnego zdania)? Poza tym kto lub co ma przesądzać o tym, jakiej pomocy udzielić: sam klient, jego rodzina czy może pracownik socjalny lub po prostu procedura? Nie są to wątpliwości wolne od ideologii i wartościowania. Na gruncie praktyki społecznej wybór kryteriów i sposobów określany jest obiektywnym (w przekonaniu ich twórców) określeniem - jako model polityki społecznej. Stąd mówi się o modelu opiekuńczym, liberalnym, demokratycznym, rezydualno-instytucjonalnym itd. Model ten przesądza o definicji pracy socjalnej, jej założeniach ani środkach przekazywanych na rzecz określonych grup osób.

Wśród definicji pracy socjalnej wyróżnia się ta sformułowana w 2000 roku przez International Federation of Social Workers:

Praca socjalna jako profesja angażuje się w zmiany społeczne, w rozwiązywanie problemów we wzajemnych ludzkich relacjach oraz we wzmocnienie i wyzwolenie ludzi dla osiągnięcia przez nich dobrostanu. Korzystając z teorii ludzkich zachowań i systemów społecznych, praca socjalna interweniuje dokładnie tam, gdzie dochodzi do interakcji ludzi z ich środowiskiem. Fundamentalne dla pracy socjalnej są zasady praw człowieka i społecznej sprawiedliwości (za: Olech 2012:334).

Definicja ta wskazuje na emancypacyjną, wręcz wyzwalającą perspektywę działań pomocowych, które nie tylko nie utrwalają systemu, ale także zmieniają go, na przykład gdy nie odpowiada on standardom, potrzebom, możliwościom członków danego społeczeństwa. Jest ona bliska definicji feminizmu (ze względu na cel) zaproponowanej przez Aleksandrę Derrę, która stwierdza:

Traktuję feminizm jako dobrą ilustrację zmiany pierwszoosobowego doświadczenia na działania, które służą poszerzaniu wolności innych, pomnażaniu dobra wspólnego. Feministyczny namysł nad nauką może nie tylko usensawniać świat i tworzyć kulturę, lecz także stać się początkiem i motywacją do zmiany życia zbiorowego i panujących w nim praktyk (Derra 2013: 207).

\section{Zasada 3D, czyli o punktach zbieżnych między pracą socjalną a feminizmem}

Biorąc pod uwagę powyższe, należy stwierdzić, że działania pomocowe (i ich teorie) i myśl feministyczną mogą łączyć zatem idee znaczenia społecznego rozwoju, emancypacji, wspólnego dobra, odpowiedzialności społecznej za dobrostan ogółu (welfare). Miejsc wspólnych, przecinających dwie płaszczyzny (lecz nie konfliktujących ich), może być znacznie więcej, na co wskazują autorzy i badacze pracy socjalnej ukierunkowanej na poznanie i poprawę 
warunków życia kobiet (Dominelli 2000, 2002, 2003, 2004a, 2004b; Payne 1997, 2008). Kazimiera Wódz oraz Jolanta Klimczak-Ziółek (ale też np. Szmagalski 2003; Adams, Dominelli, Payne 2005: 3) przekonują jednak, że społeczne/ekonomiczne/aksjologiczne kryzysy przełomu XX i XXI wieku, wywołane między innymi przez procesy globalizacyjne i zmiany w postrzeganiu zadań państwa, doprowadziły do „kształtowania się nowych paradygmatów”, w tym feministycznego, który w wielu punktach łączy się z pracą socjalną (Wódz i Klimczak-Ziółek 2014: 446, Klimczak-Ziółek 2008). Punkty zbieżne mogą stanowić pole do pogłębienia procesu pomagania czy poznania problemów społecznych, choć - jak zauważają cytowane badaczki - nie przekłada się to na działania badawcze i eksplorację niepodjętych dotąd wątków. Wynikać to może z faktu, że praca socjalna głównego nurtu, usytuowana kulturowo w przestrzeni Polski tradycyjnej, katolickiej, konserwatywnej, skłania się ku ideologii familiarystycznej „generującej obraz świata silnie dychotomizowanego, podzielonego na sferą męską i kobiecą” (Wódz i Klimczak-Ziółek 2014: 449). To mężczyzna jest „głównym żywicielem rodziny”, praca domowa, którą wykonują głównie kobiety, nie jest wymierna czy policzalna (stąd na przykład niepracującej zawodowo kobiecie nie należy się emerytura), a przedstawiciele obu płci ${ }^{52}$ mogą skorzystać z innej oferty szkoleniowej (na przykład podczas szkoleń dla mężczyzn nie przewiduje się konieczności zapewnienia opieki ich dzieciom, w przeciwieństwie do szkoleń dla kobiet).

Dlaczego tak się dzieje? Skąd wynikają zjawiska: dysproporcji (w nierównym traktowaniu mężczyzn i kobiet), dyskryminacji (obu płci przez stereotypowe traktowanie ról płciowych) i dominacji (mężczyzn, szczególnie tych dzierżących władzę - czy to w rodzinie, czy w instytucjach pomocy społecznej)? Badaczki wskazują na kilka przyczyn tego stanu, odwołując się do punktów wspólnych dla obu zakresów. Pierwszym z powodów jest wpływ środowiska na procesy socjalizacji czy - szerzej - względy kulturowe:

...dla obu (feminizmu i pracy socjalnej - A.M.K) centralną relacją jest jednostka i jej środowisko. W opcji feministycznej znajduje to wyraz w sloganie 'prywatne jest polityczne' i oznacza rozpoznawanie sytuacji kobiet jako konsekwencji relacji patriarchalnych i jako egzemplifikacji tych relacji, zaś w tradycyjnej pracy socjalnej jednostki (neutralizowane płciowo) traktowane są jako socjalizacyjny wytwór swojego środowiska społecznego (Wódz i Klimczak-Ziółek 2014: 446).

Dla pracy socjalnej „środowisko” jest bardzo ważną kategorią opisu zjawisk, co związane jest z genezą tej nowej dyscypliny akademickiej. Korzysta ona z dorobku pedagogiki społecznej, z której w dużej mierze się wywodzi.

\footnotetext{
${ }^{52} \mathrm{Z}$ zasady przyjmuje się, że są jedynie dwie płcie, określające tożsamość jednostki jako kobietę albo mężczyznę. Systemowo nie uwzględnia się przypadków tzw. trzeciej płci, transseksualizmu, problemów osób homoseksualnych czy innych niestandardowych sytuacji życiowych, wychodzących poza ustaloną normę społeczną, co samo w sobie stanowi istotny problem badawczy mieszczący się w ramach kreślonej tu perspektywy studiów genderowych, jednakże wykracza on poza pole niniejszych rozważań.
} 
W rodzinie, czy szerzej: w społeczności, w jakiej przebiegają procesy socjalizacji jednostek, ujawniają się mechanizmy dyskryminujące, upokarzające i krzywdzące kobiety.

Po drugie, kategorie feminizmu i pracy socjalnej łączy kwestia wykluczenia, choć „dla pierwszej oznacza to jednak koncentrację na kobietach jako strukturalnie i kulturowo dyskryminowanych, a dla drugiej - kategoria 'kobiecości' nie aktualizuje zorientowanej na płeć (gender) analizy i praktyki” (Wódz i Klimczak-Ziółek 2014: 447). Skutkuje to tym, że rozbieżne są zarówno diagnozy i analizy, jak i pomocowe działania, ponieważ „tam, gdzie feminizm podnosi problem przemocy ekonomicznej czy seksualnej wobec kobiet, tam mainstreamowa praca socjalna widzi rodzinę w jej funkcjonalistycznej wersji, z patriarchalną strukturą oraz do niedawna męską władzą nad kobietami jako normą” (Wódz i Klimczak-Ziółek 2014: 447).

Wykluczenie i dominacja mężczyzn często sprzyja przemocy, która jako trzeci punkt łączy feminizm z pracą socjalną (chyba najmocniej). Jednak obie sfery inaczej ją definiują, dostrzegają w odmiennych zachowaniach czy sferach życia rodzinnego (np. Campbell 1993: 69-85). Praca socjalna stara się niwelować zjawisko, łagodząc jego skutki dla członków rodziny. Feminizm natomiast upowszechnia i wprowadza w przestrzeń publiczną pojęcie „przemocy domowej”, „redefiniując normatywność relacji wewnątrzrodzinnych i patologizując przemoc wobec kobiet i dzieci” (Wódz i Klimczak-Ziółek 2014: 447) oraz zwracając uwagę na różne jej formy, ekonomiczne czy psychiczne, niekiedy trywializowane czy banalizowane przez system pomocy społecznej (co wynika głównie z braku wiedzy na dany temat i nieumiejętności udzielenia odpowiedniego wsparcia ofiarom). Z zasady jednak przemoc jest jednym ze zjawisk, które mogą zachwiać fundamentem rodziny i jej strukturą władzy. Mężczyzna-agresor jest coraz częściej, także w tradycyjnych środowiskach, uznawany za przestępcę i krzywdziciela oraz skazywany na społeczny ostracyzm (szczególnie dotyczy to pedofili i przestępców seksualnych - vide przypadek Mariusza T.). O innej sytuacji mówimy w odniesieniu do przemocy seksualnej występującej w związku małżeńskim. Społecznie akceptowane są przypadki wypowiedzi osób znanych, dotyczące niemożności zgwałcenia kobiety przez jej własnego męża.

Kolejnym wymienionym przez Wódz i Klimczak-Ziółek łącznikiem między pracą socjalną a feminizmem jest samo pojęcie gender, a właściwie „płeć”. Pomoc społeczna, wywodząca się z tradycji przedwojennych działań filantropijnych kobiet - przedstawicielek warstw wyższych, definiuje kobiety jako nie tylko predysponowane, lecz także predestynowane do wykonywania czynności dobroczynnych. Sprawia to, że pomoc zyskuje specyficzny wydźwięk, powołuje się na „idee siostrzaństwa i wiarę, że sisterhood is powerful” (Wódz i Klimczak-Ziółek 2014: 447, Hooks 1984). Kobiety posiadają przymioty pozwalające im na wykonywanie zadań pomocowych, wcielanie się w tak zwane helping 
professions $^{53}$. Trzeba jednak zwrócić uwagę na prestiż tych zawodów, bowiem innym poważaniem (także w wymiarze finansowym) cieszyć się będą lekarze, a innym - pracownice socjalne, pielęgniarki, asystentki rodziny czy opiekunki środowiskowe, czyli osoby należące do jednej kategorii zawodowej: „pomagaczy”. Prestiż idzie tutaj w parze z zarobkami, które - podobnie jak w innych sfeminizowanych zawodach (nauczycielki, urzędniczki niższego szczebla) - są zdecydowanie niższe niż tak zwana średnia krajowa (ich poziom wynika także z decyzji władz samorządowych, które w myśl przepisów prawa administracyjnego stanowią organ prowadzący dla instytucji pomocowych).

Wódz i Klimczak-Ziółek podsumowują powyższe refleksje dotyczące punktów zbieżnych, stwierdzając: „Perspektywa feministyczna skupia się na wzroście i rozwoju potencjału kobiecego oraz właściwościach ich środowiska, które podtrzymuje lub hamuje ich samostanowienie i zakres oraz formy partycypacji społecznej” (Wódz i Klimczak-Ziółek 2014: 448). Autorki zaproponowały, by zawrzeć to w kilku rekomendacjach dla paradygmatu feministycznego pracy socjalnej:

\begin{tabular}{|l|}
\hline \multicolumn{1}{|c|}{ Paradygmat feministyczny } \\
\hline Kobiety jako kategoria i grupa społeczna są dyskryminowane. \\
\hline $\begin{array}{l}\text { Ten stan można zmienić, bo kategoria gender jest kulturowo kon- } \\
\text { struowana. }\end{array}$ \\
\hline Ten stan TRZEBA zmienić. \\
\hline $\begin{array}{l}\text { Mogą tego dokonać samoorganizujące się i współpracujące kobie- } \\
\text { ty. }\end{array}$ \\
\hline
\end{tabular}

Źródło: Wódz i Klimczak-Ziółek 2014: 448

Co zatem należałoby badać, korzystając z powyższego paradygmatu? Gdy myślimy o pracy socjalnej (1) w kategoriach instytucjonalnych, to analizujemy sposoby działania instytucji - pomocowych, ale też tradycyjnych - rodzin, społeczności lokalnych czy grup zawodowych. Wówczas należy rekonstruować fundamenty systemu społecznego, będącego nośnikiem patriarchalnych, męskozorientowanych wartości. Odkrywamy wtedy, jak wpływa to na sposób udzielania pomocy. (2) W ujęciu funkcjonalno-strukturalnym należy zanalizować stratyfikację społeczną opartą na płci i poszukać tych miejsc, gdzie kobiety są wykluczone czy marginalizowane, i próbować opisać problem ich nieobecności w miejscach redystrybucji dóbr społecznie cenionych. Nie mam tu na myśli jedynie środków finansowych, ale też na przykład możliwość zatrudnienia, wykształcenie, czy też możliwość korzystania ze specjalistycznego

${ }^{53}$ Przymioty kobiet, rzekomo pozwalające im wykonywać określone role zawodowe, stanowią efekt esencjalizacji, która odległa jest od feministycznego dyskursu. 
leczenia (np. na HIV/AIDS - Wojciechowska 2003). (3) Perspektywa organizacyjna zaś zwraca uwagę na wzory zawodowe i kulturę zarządzania, co jest szczególnie ważne w pracy socjalnej, gdzie większość prac wykonywana jest przez kobiety. Ostatnie wymienione przez Wódz i Klimczak-Ziółek jest (4) pole dyskursu, gdy „wczytujemy się w pseudoneutralny język oficjalnych dokumentów standaryzujących i normatywizujących wykonywanie zawodu pracownika socjalnego oraz odgrywanie roli beneficjenta, gdy znajdujemy w nich klisze stereotypowego konceptualizowania kobiecości i męskości i gdy te klisze uramowane są dominującą ideologią (obecnie coraz częściej neoliberalną)” (Wódz i Klimczak-Ziółek 2014: 449).

\section{Feminizacja pracy socjalnej ${ }^{54}$}

Inny, pojemny pomysł na swoiste „odkrywanie” feminizmu i kwestii płciowych w pracy socjalnej miał Tomasz Biernat, który wskazał na oblicza feminizacji działań pomocowych w szerokiej perspektywie (Biernat 2012). Feminizacja według tego autora jest „dominacją kobiet w jakiejś dziedzinie, na przykład w pielęgniarstwie” (Biernat 2012: 461). Jednak trzeba się zastanowić, o jakiego rodzaju dominacji tu mowa? Wymienione dziedziny życia społecznego i kategorie zawodowe (pielęgniarstwo czy praca socjalna) świadczą jedynie o liczebnej dominacji kobiet, nie zaś o możliwości realnego wpływu na rzeczywistość. Być może zatem należałoby mówić o wątpliwej czy problematycznej feminizacji, szczególnie po przeanalizowaniu wyróżnionych obliczy pracy socjalnej. Jakie sfery Biernat wymienia? Autor wskazuje na zagadnienia (1) feminizacji zawodu (struktury zatrudnienia), (2) feminizacji klientów pomocy społecznej, (3) feminizacji działań pomocowych, (4) feminizacji problemów społecznych oraz (5) feminizacji teorii pracy socjalnej (Biernat 2012: 461473). Można dodać do nich inne: feminizację dyskursu pomocy, feminizację instytucji pomocowych działających w trzecim sektorze itp. Każdy z tych zakresów wywołuje innego typu wątpliwości o rzeczoną „dominację” kobiet (zwłaszcza w perspektywie krytycznej czy emancypacyjnej). Być może warto byłoby w tym kontekście zapytać o proces maskulinizacji i jego zakres? Odpowiedź jest czytelna: ma miejsce wyraźna maskulinizacja polityki społecznej, maskulinizacja przepisów prawa, maskulinizacja finansów, zatem obszarów związanych z władzą, środkami, przywilejami oraz realną dominacją i wpływami na kształt praktyk społecznych.

Według danych z Raportu Ministerstwa Pracy i Polityki Społecznej z 2013 ro$\mathrm{ku}^{55}$ zatrudnienie $\mathrm{w}$ instytucjach pomocy i opieki wyniosło 115 423,9 etatów,

\footnotetext{
${ }^{54}$ Śródtytuł zapożyczony jest od T. Biernata, autora tekstu pt. Oblicza feminizacji pracy socjalnej (2014).

${ }^{55}$ Coroczne raporty Ministerstwa Pracy i Polityki Społecznej dostępne są na stronie internetowej: URL = <http://www.mpips.gov.pl/pomoc-spoleczna/raporty-i-statystyki/statystyki-pomocy-spolecznej/ >.
} 
na których zatrudnionych było ponad 121 tysięcy osób. Wśród nich 22 tysiące stanowili pracownicy socjalni i pracownice socjalne, przy czym ponad 94\% ogółu pracowników to kobiety (Napierała 2012: 360). W skali europejskiej jest to znacząca liczba, szczególnie że wśród pracowników szeroko pojmowanego unijnego rynku pracy $11 \%$ zatrudnionych stanowią pracownicy socjalni (Czechowska-Bieluga 2014: 314).

Pracownicy socjalni należą do grupy zawodowej określanej jako helping professions. Znajdują się w niej obok lekarzy, pielęgniarek, opiekunów społecznych. Wspólną ich cechą jest pomaganie innym w rozwiązywanie ich problemów życiowych (psychicznych, zdrowotnych, socjalnych itd.). Jednak nie można powiedzieć, że jest to grupa jednorodna. Różnice są wielorakie, poczynając od statusowych, a na finansowych kończąc, co widać każdego roku, gdy lekarze podejmują strajk, by podpisać jak najkorzystniejsze dla siebie kontrakty z Ministerstwem Zdrowia. O strajkach pracowników socjalnych nikt nie słyszał, dzieje się wręcz odwrotnie: plany nowelizacji ustawy o pomocy społecznej wprowadzają nie tylko chaos informacyjny, ale też niepewność zatrudnienia (asystenci rodziny zwykle zatrudniani są na mocy umowy zlecenia, a zatem „umowy śmieciowej”, w ramach realizowanych przez gminy projektów). Polityka wobec instytucji pomocowych zakłada w nowo planowanych zasadach prywatyzację usług socjalnych, co powodować może restrukturyzację zatrudnienia, innymi słowy - zwolnienia w szeregach pracowników socjalnych.

Jak w takim razie funkcjonują pracownicy socjalni/pracownice socjalne w systemie pomocy? Prowadzone są coraz liczniejsze badania, by poznać środowisko pracowników pomocy społecznej (z powodu instytucjonalizacji i dyscyplinaryzacji pracy socjalnej). Jednym z nich jest badanie zrealizowane w Instytucie Spraw Publicznych w 2010 roku w ramach prac Laboratorium Innowacji Społecznej pod kierownictwem Marka Rymszy (Rymsza 2012: 13). Badania miały służyć celom instytucjonalnym, systemowym, jednak zakładały nie tylko badanie tendencji, ale też pogłębienie wiedzy na temat tożsamości (nie tylko) zawodowej pracowników socjalnych ${ }^{56}$. Analizy nie skupiają się wokół wątków tożsamościowych, wątkach płci, choć sama instytucja (ISP A.M.K.) podejmuje pytania dotyczące równości kobiet i mężczyzn w społe-

\footnotetext{
56 „Badanie ilościowe miało w głównej mierze charakter eksploracyjny (poznawczy) i koncentrowało się na następujących zagadnieniach: współczesny portret pracowników socjalnych, ze szczególnym uwzględnieniem nastawienia badanych wobec własnej aktywności zawodowej, tożsamość zawodowa pracowników socjalnych (jak określają oni istotę swojej profesji), profesjonalizacja pracy socjalnej - rozumianej jako proces zarówno budowania wspomnianej tożsamości zawodowej i etosu zawodowego, jak i kształtowania się ścieżek rozwoju zawodowego, role zawodowe i potencjał modernizacyjny pracowników socjalnych (rekonstrukcja ról odgrywanych w codziennej działalności, badanie zainteresowania nowymi rolami, zwłaszcza związanymi z pracą socjalną metodą środowiskową)" (Rymsza 2012: 19-20). Cytuję powyższe cele, by pokazać brak kwestii płci zawartych w projektowanym i przeprowadzonym badaniu. Z uwagi na ich powszechność i ogólnopolski charakter badań uznaję to za znaczącą wadę i poznawczą stratę.
} 
czeństwie czy prawie (na przykład program Obserwatorium Równości Płci). $\mathrm{W}$ analizach sytuacji pracowników socjalnych podejmowano jedynie sporadycznie wątek tożsamości jednostek i grup (Trawkowska 2012: 143). Co interesujące, badania te zostały przeprowadzone dekadę po tych zrealizowanych w tym samym środowisku zawodowym (Brągiel i Kurcz 2002, Rymsza i in. 2012), jednak i tam nieobecny jest wymiar kulturowy płci. Nawiązując do klasycznego podziału na kulturę i naturę (jako czynników kształtujących tożsamość, w tym tożsamość płciową), można powiedzieć, że zamiast kultury pojawia się natura. Do ontologicznej kategorii natury odwołuje się bowiem Tomasz Biernat w swoim tekście, tłumacząc wybory zawodowe pracownic socjalnych: „Wykonaniu tej profesji sprzyjają predyspozycje psychospołeczne, takie jak: opiekuńczość, troskliwość, współczucie, empatia, umiejętności komunikacyjne, które kobiety posiadają $\mathrm{w}$ większym stopniu niż mężczyźni" (Duran 1988; za: Biernat 2012: 462). Szukając motywacji podjęcia zawodu pracownika socjalnego, należy sięgnąć nie tylko do cech osobowych: „Zawód (...) jest wybierany przez kobiety także $\mathrm{z}$ innych powodów, takich jak dostępność kształcenia, instytucjonalizacja i etatyzacja, które dają względne poczucie bezpieczeństwa zatrudnienia, łatwość godzenia ról rodzinnych i zawodowych oraz możliwość pracy z ludźmi” (Biernat 2012: 462). Cena, jaką kobiety płacą za te wybory, jest rażąco nieproporcjonalna do osiąganych profitów. Mężczyźni pojawiają się zaś w sferach, gdzie sprawuje się władzę, takich jak polityka społeczna, władze samorządowe, polityka (traktowana jako skonfliktowana zwykle arena interesów partyjnych). Należy zauważyć, że kierownikami instytucji pomocowych są kobiety, co dodatkowo obniża status tego stanowiska. Jest on na tyle niski, że praca w tych instytucjach nie stanowi dla mężczyzn celu, przedmiotu aspiracji czy ambicji.

Wizerunek pracowniczek socjalnych i ich klientek podtrzymują media. Jeśli nawet pojawią się informacje dotyczące pomocy społecznej, to pokazywani są klienci, co ma wywołać u odbiorców współczucie lub żal, albo „źli” pracownicy socjalni, którzy odbierają dzieci rodzicom lub zaniedbują swoje obowiązki. Działania na rzecz kształtowania publicznej wiedzy w zakresie pomocy społecznej są wpisane w zmiany systemowe. „Służą temu celowi działania informacyjne prowadzone $\mathrm{w}$ mediach, ale także promowanie dokonań kadr socjalnych wśród lokalnych decydentów i szerokiej opinii publicznej” (Sikora 2002: 43). Jednak w prasie i telewizji promowany jest obraz nie tyle zaangażowanej animatorki życia lokalnego, co bezdusznej kobiety urzędniczki (Brągiel i Kurcz 2002). Używane tam formy językowe są przy tym męskie - w ośrodku pomocy społecznej pracują bowiem: pracownik socjalny, dyrektor, kierownik, aspirant pracy socjalnej (chociaż zazwyczaj są to kobiety). Zatem język odsłania to, co ukryte, niekiedy lepiej i efektywniej niż innego rodzaju działania, na przykład coroczne święto pracowników socjalnych. 
21 listopada ${ }^{57}$ każdego roku obchodzony jest Dzień Pracownika Socjalnego: święto, które przypomina Dzień Kobiet z czasów PRL-u. W ramach tego święta instytucje pomocowe organizują specjalne uroczystości. Wręczane są wówczas nagrody dla wyróżniających się urzędniczek - pracowniczek socjalnych, organizowane są akademie, w których uczestniczą zaproszeni goście (włodarze miasta, kierownicy zaprzyjaźnionych instytucji, sponsorzy, sprzymierzeńcy, media, księża itd.). Święto, zamiast stać się okazją do refleksji nad zawodem (właściwie jest to Międzynarodowy Dzień Życzliwości), rolą społeczną, jest usankcjonowaniem przywilejów wybranek czy wybrańców, pracowników czy pracowniczek. Ważne jest także, kto będzie gościem uroczystości, bowiem ich obecność świadczy o pozycji w lokalnym środowisku kierownika czy dyrektora danej instytucji. Rytuał ten uprawomocnia zatem mechanizmy opresyjne, pozwalając kobietom poczuć się wyjątkowo, w rzeczywistości je upokarzając.

Pracownicy socjalni nie mają płci, podobnie jak ich klienci i problemy społeczne, takie jak bieda (Golczyńska-Grondas 2002: 151). Biernat zauważa, że w systemie pomocowym kobieta jest także głównym „delegatem systemu rodzinnego" (Biernat 2012: 463). Powołuje się na autorskie badania w województwie kujawsko-pomorskim, według których 80\% klientów pomocy społecznej stanowią kobiety. Dzieje się tak na wsiach, w miastach o wysokim poziomie bezrobocia, ale także na terenach popegeerowskich (Perepeczko 2002: 35). Żony często czują się odpowiedzialne za utrzymanie rodziny (zatem wbrew kulturowej normie, według której to mężczyzna jest tzw. „głową rodziny”). Są to rodziny o niskim statusie społecznym i materialnym, realizujące tradycyjny model rodziny patriarchalnej, pełnej patologicznych form współżycia (agresja, molestowanie psychiczne czy seksualne, alkoholizm, itd.). Ma miejsce zatem feminizacja środowiska klientów, choć z drugiej strony - zauważyć należy paralelne do niego, znów paradoksalne zjawisko - maskulinizacji problemów spolecznych. Mężczyźni są sprawcami przemocy, są uzależnieni od alkoholu, zaniedbują dzieci i nie wypełniają swoich zadań w rodzinie. Zatem kobiety, ale i dzieci58 (gdy są nieletnie nie mogą same wnioskować o pomoc) są ich ofiarami. Dlaczego się tak dzieje? Klient-mężczyzna wstydzi się przed pracownikiem socjalnym, czyli kobietą, przyznać nie tylko do swojej słabości czy niezaradności, ale też do czynów o charakterze przestępczym, i to takich, których ofiarą jest kobieta. Kulturowo wymaga się od niego, by nie okazywał skruchy, nie przyznawał się do błędów, bowiem takie zachowania wpływają negatywnie na jego wysoki status, przez co może stracić swoją uprzywilejowaną, dominującą pozycję. Relacja pomocowa przebiega więc pomiędzy kobietami (Biernat 2012: 464), co stanowi niewykorzystany dotąd

\footnotetext{
${ }^{57} 21$ listopada obchodzony jest corocznie Światowy Dzień Życzliwości.

${ }^{58}$ Status kobiet i dzieci jest podobny. Obie grupy są w jakiś sposób kulturowo upośledzone, a ich rola jest bierna i podrzędna wobec aktywnego mężczyzny.
} 
potencjał - badawczy, praktyczny czy systemowy. Być może bowiem należy mówić o konieczności redefinicji wzorów działania pomocowego? Biernat zadaje inne trafne pytanie: „Czy płeć nie jest czynnikiem, który powinien być brany pod uwagę w edukacji i organizacji pomocy społecznej?” (Biernat 2012: 464). Z jednej strony płeć może utrudniać współpracę między pracownikiem socjalnym a klientem, a nawet ją uniemożliwiać czy blokować, z drugiej zaś sensownie skonceptualizowana i systemowo wykorzystana, może być nową szansą w pracy socjalnej. Włączenie kwestii płci tłumaczy zatem zachowania klientów, na przykład tych uznawanych za „roszczeniowych”. Pretensje i roszczenia mogą być tak naprawdę skutkiem innych uwarunkowań, związanych $\mathrm{z}$ chęcią zachowania wizerunku macho przez mężczyzn. Dlatego tak ważne jest włączenie do grupy nabywanych umiejętności zawodowych pracowników socjalnych kompetencji interpretatywnych, tak jak to się dzieje w działaniach poradniczych (Kargulowa 2007). Alicja Kargulowa wyposaża doradcę zawodowego, ale też życiowego, w umiejętność analizowania przyczyn zachowań (swoich i klienta) oraz interpretowania ich w kontekście posiadanych doświadczeń, wiedzy, stereotypów czy sądów. Ta niezwykle trudna umiejętność, pozwalająca na ewaluację działań, winna stać się kompetencją pracowników socjalnych, którzy na co dzień mają do czynienia z ludźmi, ich biografiami i problemami. „Tak więc udziat kobiet $w$ sferze biedy bywa trojaki: tkwią wewnątrz, wydobywają się z biedy dążąc do zewnątrz albo - pomagają innym z zewnątrz" (Supińska 2014: 481).

\section{Zakończenie}

Michael Payne (1997) czy Lena Dominelli (2000, 2002, 2003, 2004a, 2004b) definiują pracę socjalną jako działanie społeczne mające u swych podstaw myślenie krytyczne. Dominelli wskazuje na trzy główne podejścia w pracy socjalnej: (1) terapeutyczne, (2) podtrzymując i (3) emancypacyjne (Dominelli 1998: 3-5), przy czym, jak zostało wyżej zaznaczone, dla działań pomocowych, ale i myślenia feministycznego czy w kategoriach gender, ważna jest ostatnia z nich.

W Polsce niewiele jest badaczek podejmujących problem feministycznej pracy socjalnej, podobnie jak prac badawczych $\mathrm{z}$ tego zakresu. Z drugiej strony, można jednak mówić o swoistym pozytywnym fenomenie, bowiem znaczące miejsce w grupie twórców i badaczy zajmują kobiety różnych pokoleń i tradycji, między innymi Ewa Marynowicz-Hetka, Anna Kotlarska-Michalska, Ewa Kantowicz. Ta paradoksalna dwoistość, kryjąca sprawy płci, kobiet, kobiecości, feminizmu itp., powoduje, że są one odsuwane czy ignorowane. Krzysztof Frysztacki zadaje pytanie o zasadność przyjmowania kobiecej perspektywy: „Czy wyróżnianie czynników, aspektów, zmiennych traktowanych jako specyficznie kobiece (by tym słowem podkreślić nieuchwytność owego znaczenia), odzwierciedlające wyjątkowość kobiecości, jest usprawiedliwione w naukach 
społecznych, w tym pracy socjalnej, czy też nie?” (2014: 238). Frysztacki stawia argumenty „za” i „przeciw”. Jeden z nich brzmi:

Uwzględniając takie cechy (zmienne), analizowane w rozlicznych badaniach, jak: podział na mężczyzn i kobiety, ludzi młodszych i starszych, mieszkańców wsi i miasta, osoby oraz środowiska uboższe i zamożniejsze, osoby posiadające niższe i wyższe wykształcenie, bardzo często łączymy z nimi charakterystykę poszczególnych zjawisk i zagadnień. Czy pierwszy z tych podziałów jest ważniejszy, bardziej wpływowy niż pozostałe? Odpowiem krótko: nie (Frysztacki 2014: 239).

To nie jest odosobnione zdanie, bowiem inna badaczka, Kazimiera Król pisze: „Zdaję sobie sprawę z faktu, że nie należy dzielić - ze społecznego punktu widzenia - działaczy obywatelskich według kryterium płci, ale w historii bardzo często nie doceniono i nie zauważano w pełni ról i dokonań, a także osiągnięć kobiet w sferze społecznej, ekonomicznej czy politycznej, a wręcz je marginalizowano" (Król 2014: 432). To zdanie zaskakuje, gdyż z jednej strony podkreśla nasze kobiece upośledzenie społeczne w historii, które - z drugiej strony dodatkowo powinno być skrywane, nieujawniane, wbrew potrzebom i woli kobiet, wbrew ich krytycznemu myśleniu i walce o równouprawnienie.

Przeciwstawienie się temu sposobowi myślenia i naukowego działania wymaga świadomej i przemyślanej decyzji. Jako badaczka, po analizie zjawisk i ich krytycznej interpretacji (por. Frysztacki 2014), podejmuję świadomą decyzję, że problemy i kwestie społeczne czy socjalne należy widzieć z perspektywy badaczki zaangażowanej, korzystając z perspektywy women's/gender/feminist studies. To zadanie nie jest jedynie obowiązkiem wynikającym z metodologii badań czy praktyki pomocy, ale także wymaga swoistego nastawienia, docenienia, uwrażliwienia na kwestie kobiet. Tomasz Kaźmierczak mówi wprost, że natura pracy socjalnej jest genderowa, bo: „(1) jej funkcja polega na przedłużeniu tradycyjnej opiekuńczo-wychowawczej roli kobiet; (2) jest liczebnie zdominowana przez kobiety; (3) w jej wczesnym stadiach rozwojowych wybitny był udział kobiet” (2014: 503). Determinuje ona sposób patrzenia na badane zjawiska i realizację zadań z zakresu pomocy i opieki. Należy pamiętać o tym, że „kontekst społeczny, polityczny i rodzinny znacząco wpływa na problemy kobiet” (Braverman 2003: 16-17; za: Gawęcka 2014: 767). Trzeba przy tym skupić się nad „rozpoznaniem ograniczeń kobiet w zakresie sfery osobistej, ekonomicznej, rodzinnej i publicznej”, co prowadzi do konstatacji, że to, „co osobiste jest polityczne, czyli macierzyństwo kobiety, wychowanie dzieci, małżeństwo to nie tylko wydarzenia przełomowe w jej cyklu życiowym, lecz także instytucje, które wyznaczają kobietom z góry zaprogramowany i określony legat kulturowy” (Braverman 2003: 16-17; za: Gawęcka 2014: 767). Ważna jest tu weryfikacja własnego życia i doświadczenia ze względu na czynniki strukturalne, co prowadzić może do dostrzeżenia mechanizmów opresji przez kobiety (Morrinson van Voorihis 1999: 368; za: Gawęcka 2014: 772). Szczególnie istotne zaś jest, by „odnosić się do różnicujących aspektów niesprawiedliwości społecznej wśród kobiet wynikających z takich czynników, jak: kolor 
skóry, klasa społeczna, wiek, zarobki, orientacja seksualna, wiek i inne” (Morrinson van Voorihis 1999: 368; za: Gawęcka 2014: 772). Łączy się to z perspektywą jednostkową, która ma na celu „uwrażliwienie na cykl życia kobiety, czyli jaki wpływ na występowanie objawów i relacji interpersonalne w cyklu jej życia ma menstruacja, dojrzewanie, ciąża, poród czy menopauza” (Braverman 2003: 16-17; za: Gawęcka 2014: 767). W końcu też należy zwrócić uwagę na fakt specyficznych relacji między kobietami, które stanowią źródło pomocy, a system naturalnego wsparcia, tak innego od tego tworzonego przez kobiety tak, by „wzmacniać (empower) kobiety zarówno indywidualnie, jak i kolektywnie, by odmieniały siebie oraz warunki środowiskowe i struktury, które są wobec nich opresyjne" (Morrinson van Voorihis 1999: 368; za: Gawęcka 2014: 772).

Można zauważyć, że formuje się nowe pokolenie badaczek, korzystających nie tylko z perspektywy kobiecej, ale i z myśli krytycznej. Uznaję to za znaczący potencjał dla (roz)budowy myśli - zarówno feministycznej/genderowej, jak i z zakresu pracy socjalnej. Feminizm i praca socjalna mają bowiem wyraźnie wiele wspólnego. Za Kazimierą Wódz i Jolantą Klimczak-Ziółek powtarzam słowa, które brzmią raczej jak manifest niż naukowy wniosek:

Praca socjalna ma być przestrzenią otwartą dla głosów kobiet, przestrzenią, w której te głosy mają być słuchane i uznawane za ważne. Za ważne i społecznie znaczące uznane mają być także wytwory pracy kobiecej, te opłacane, jak i te nieodpłatne, te wykonywane w miejscach publicznych, jak i te wykonywane w zaciszach domów, te wykonywane dla innych i te wykonywane dla siebie. Wprowadza się nowe kryteria oceny i tworzy nowe hierarchie wartości, tak, by tak zwane doświadczenia kobiece i kobiece potrzeby znajdowały się w centrum i były wysoko waloryzowane (Wódz i Klimczak-Ziółek 2014: 452).

Odnieść je należy jednak do obu płci i poprzez kulturowe wyznaczniki na nowo sformułować zadania i praxis pracy socjalnej, a także podejmować rzeczone wątki w procesie kształcenia przyszłych pracowników socjalnych (Leskošek 2009).

\section{Bibliografia}

Adams, R., Dominelli, L., Payne, M. 2002. Critical Perspectives in Social Work. New York: Palgrave/MacMillan.

Adams, R., Dominelli, L., Payne, M. 2005. Social Work Futures. Crossing Boundaries, Transforming Practice. New York: Palgrave/MacMillan.

Bates, J., Thompson, N. 2002. Men, Masculinity and Social Work. C. Gruber, H. Stefanov, red. Gender in Social Work. Promoting Equality. Dorset: Russell House Publishing.

Beckett, Ch. 2010. Podstawy teorii dla praktyków pracy socjalnej. Przeł. M. Jasiński, B. Maliszewska. Warszawa: Wydawnictwo Akademii Pedagogiki Specjalnej. 
Bieńko, M. 2012. Dylematy profesji i roli w refleksyjnym projekcie tożsamości współczesnego pracownika socjalnego na przykładzie pracowników powiatowych centrów pomocy rodzinie. M. Rymsza, red. Pracownicy socjalni i praca socjalna $w$ Polsce: między stużbq a urzędem: 93-120. Warszawa: Instytut Spraw Publicznych.

Biernat, T. 2014. Oblicza feminizacji pracy socjalnej. A. Kotlarska-Michalska, red. Kobiety $w$ pracy socjalnej: 461-473. Poznań: Wydawnictwo Uniwersytetu Adama Mickiewicza.

Braveman, L. 2003. Feminizm i terapia rodzin: przyjaciele czy wrogowie. L. Braveman, red. Podstawy feministycznej terapii rodzin. Gdańsk: Gdańskie Wydawnictwo Psychologiczne.

Brągiel J., Kurcz A. 2002. Pracownik socjalny. Wybrane problemy zawodu $w$ okresie transformacji społecznej. Opole: Wydawnictwo Uniwersytetu Opolskiego.

Campbell, A. 1993. Men, Women and Aggression. New York/London: Basic Books/Harpercollins.

Czechowska-Bieluga, M. 2014. Poziom zadowolenia z życia pracowników socjalnych a płeć. A. Kotlarska-Michalska, red. Kobiety w pracy socjalnej: 313-355. Poznań: Wydawnictwo Uniwersytetu Adama Mickiewicza.

Derra, A. 2013. Kobiety (w) nauce. Problem płci we wspótczesnej filozofii nauki i w praktyce badawczej. Warszawa: Wydawnictwo Scholar.

Dominelli, L. 2002. Anti-Oppressive Social Work Theory and Practice. London: Palgrave.

Dominelli, L. 2004. Social Work: Theory and Practice for a Changing Profession. Cambridge: Polity Press.

Dominelli, L., Thomas Bernard, W. red. 2003. Broadening Horizons: International Exchanges in Social Work. Aldershot: Ashgate.

Duran, J. 1988. The Feminization of Social Work. A Philosophical Analysis. International Journal of Applied Philosophy, 4:85-90.

Frysztacki, K. 2014. Problemat kobiecy $w$ pracy socjalnej: czynniki na rzecz analizy $i$ argumenty na rzecz interpretacji, A. Kotlarska-Michalska, red. Kobiety $w$ pracy socjalnej: 235-244, Poznań Wydawnictwo Uniwersytetu Adama Mickiewicza

Gawęcka M. 2014. Kwestia kobieca jako wyznacznik „praxis” pracy socjalnej z przypadkiem, A. Kotlarska-Michalska, red. Kobiety $w$ pracy socjalnej: 764-776. Poznań: Wydawnictwo Uniwersytetu Adama Mickiewicza.

Golczyńska-Grondas, A. 2002. Postawy przedstawicieli służb społecznych. Szanse i ograniczenia $w$ działaniach przeciw biedzie. E. Tarkowska, red. Przeciw biedzie: programy, pomysły, inicjatywy: 151-163. Warszawa: Oficyna Naukowa.

Herrmann, P. 2010. Ustugi socjalne jako instrument integracji - z perspektywy Unii Europejskiej. A. Brandstaetter, P. Herrmann, C. O’Connell, red. Definiowanie ustug socjalnych $w$ kontekście europejskim - od ogółu do szczegółu. Przeł. E. Jaroszewska, M. Witkowska: 85-96, Warszawa: Wydawnictwo Wyższej Szkoły Pedagogicznej Towarzystwa Wiedzy Powszechnej w Warszawie. 
Hicks, S. 2008. Gender role models... who needs 'em?!. Qualitative Social Work: 7 (1): 42-59.

Hooks, B. 1984. Feminist Theory: From Margin to Center. Cambridge, MA: South End Press.

Leskošek, V., red. 2009. Teaching Gender in Social Work: Teaching with Gender. European Women's Studies in International and Interdisciplinary Classrooms. Utrecht: Athena 3.

Kantowicz, E. 2014. Rola kobiet $w$ organizacji działania społecznego i rozwoju szkót pracy socjalnej $w$ Europie - analiza historyczno-porównawcza. A. KotlarskaMichalska, red. Kobiety $w$ pracy socjalnej: 115-127. Poznań: Wydawnictwo Uniwersytetu Adama Mickiewicza.

Kantowicz, E. 2006. Praca socjalna $w$ Europie Inspiracje teoretyczne i standardy ksztatcenia. Olsztyn: Uniwersytet Warmińsko-Mazurski.

Kargulowa, A. 2007. Pomoc przez porady. Statyczna „versus” procesualna struktura poradnictwa $w$ przestrzeni życia społecznego. E. Marynowicz-Hetka, red. Pedagogika społeczna. Debata: 444-465, Warszawa: PWN.

Kawczyńska-Butrym, Z., red, współautor. 2001. Koncepcje opieki i zawody opiekuńcze. Pracownicy socjalni i pielęgniarki. Olsztyn: Wydawnictwo Uniwersytetu Warmińsko-Mazurskiego.

Kaźmierczak, T. 2014. Mężczyźni - pracownicy socjalni. A. Kotlarska-Michalska, red. Kobiety $w$ pracy socjalnej: 501-514. Poznań: Wydawnictwo Uniwersytetu Adama Mickiewicza.

Klimczak-Ziółek, J. 2008. Przeciw wykluczaniu kobiet, czyli słów kilka o feministycznej pracy socjalnej. K. Wódz, S. Pawlas-Czyż, red. Praca socjalna wobec nowych obszarów wykluczania społecznego: modele teoretyczne, potrzeby, praktyki: 83-93. Toruń: Wydawnictwo Edukacyjne AKAPIT.

Kotlarska-Michalska, A. 2014. Wprowadzenie do problematyki kobiet w pracy socjalnej, czyli o różnorodności ról kobiecych $w$ tworzeniu i realizowaniu pracy socjalnej, wychowawczej i społecznej. A. Kotlarska-Michalska, red. Kobiety $w$ pracy socjalnej: 927. Poznań: Wydawnictwo Uniwersytetu Adama Mickiewicza.

Król, K. 2014. Rola kobiet sukcesu we wspieraniu pracy socjalnej. A. KotlarskaMichalska, red. Kobiety $w$ pracy socjalnej: 431-442. Poznań: Wydawnictwo Uniwersytetu Adama Mickiewicza.

Marzec-Holka, K., red. 2003. Pomoc społeczna, praca socjalna. Teoria i praktyka. Bydgoszcz: Wydawnictwo Akademii Bydgoskiej.

Morrinson van Voorihis, R. 1999. Feminist Theories and Social Work Practice. R.R. Greene, red. Human behavior theory i social work practice: 351-388. New York: Walter de Gruyter.

Napierała, K. 2014. Kobieta pracownik socjalny. Blaski i cienie zawodu. A. KotlarskaMichalska, red. Kobiety w pracy socjalnej: 337-363. Poznań: Wydawnictwo Uniwersytetu Adama Mickiewicza. 
Olech, A. 2012. Praca socjalna a inne profesje: punkty styczne i rozłaczne. M. Rymsza, red. Pracownicy socjalni i praca socjalna $w$ Polsce: między stużbą a urzędem: 331348. Warszawa: Instytut Spraw Publicznych.

Orme, J. 2012. Feministyczna praca socjalna. M. Gray, S.A. Webb, red. Praca socjalna. Teorie i metody: 93-107. Warszawa: PWN.

Payne, M. 2008. What is Professional Social Work?. Bristol: Policy Press.

Payne, M. 1997. Modern social work theory (2nd ed.). Chicago, Illinois: Lyceum Books.

Perepeczko, B. 2002. Swoistość biedy $w$ rodzinach rolniczych $i$ jej oswajanie. E. Tarkowska, red. Przeciw biedzie: programy, pomysły, inicjatywy: 32-41. Warszawa: Oficyna Naukowa.

Rymsza, M. 2012. Wprowadzenie. M. Rymsza, red. Pracownicy socjalni i praca socjalna w Polsce: między stużbą a urzędem: 11-33. Warszawa: Instytut Spraw Publicznych.

Sikora, P. 2002. Profesjonalizacja pracy socjalnej $w$ warunkach transformacji systemu pomocy społecznej $w$ województwie opolskim. J. Brągiel, A. Kurcz, red. Pracownik socjalny. Wybrane problemy zawodu $w$ okresie transformacji spolecznej: 35-55. Opole: Wydawnictwo Uniwersytetu Opolskiego.

Supińska, J. 2014. Wartości uznane za kobiece $w$ koncepcjach postępu społecznego. A. Kotlarska-Michalska, red. Kobiety w pracy socjalnej: 475-487. Poznań: Wydawnictwo Uniwersytetu Adama Mickiewicza.

Szmagalski, J. 2003. Teorie antydyskryminacyjnej pracy socjalnej $w$ erze globalizacji. K. Marzec-Holka, red. Pomoc społeczna, praca socjalna. Teoria i praktyka: 117-127. Bydgoszcz: Wydawnictwo Akademii Bydgoskiej.

Trawkowska, D. 2012. Pracownicy socjalni jako środowisko zawodowe Portret czy portrety pracowników socjalnych?. M. Rymsza, red. Pracownicy socjalni i praca socjalna w Polsce: między stużbą a urzędem: 142-154. Warszawa: Instytut Spraw Publicznych.

Wojciechowska, J. 2003. Potrzeba wsparcia dla kobiet żyjących z HIV/ AIDS. K. MarzecHolka, red. Pomoc społeczna, praca socjalna. Teoria i praktyka: 577-583, Bydgoszcz: Wydawnictwo Akademii Bydgoskiej.

Wódz K., Klimczak-Ziółek J. 2014. Feministyczna perspektywa (w) pracy socjalnej. A. Kotlarska-Michalska, red. Kobiety w pracy socjalnej: 445-460. Poznań: Wydawnictwo Uniwersytetu Adama Mickiewicza.

\section{Źródła internetowe}

URL = <http://www.mpips.gov.pl/pomoc-spoleczna/raporty-i-statystyki/statystykipomocy-spolecznej/statystyka-za-2013/>

URL = <http://www.mpips.gov.pl/pomoc-spoleczna/raporty-i-statystyki/statystykipomocy-spolecznej/> 


\begin{abstract}
The aim of the article is to present the rare and uncommon perspective in social work definied as a scientific or academic discipline, but also as supportive activities. The author includes women's/gender/feminist studies to analysis concerning professional social work, social policy, social law etc. The article presents the acts of oppressions described by contemporary theories what appear in help's practice. It explains the roots of these mechanisms and points the possibilities of solutions.
\end{abstract}

Keywords: social work; gender studies; social policy; oppression; discrimination. 